\title{
Why national and international legitimacy beliefs are linked: Social trust as an antecedent factor
}

\author{
Lisa Maria Dellmuth ${ }^{1} \cdot$ Jonas Tallberg $^{2}$ (1)
}

Published online: 15 December 2018

(C) The Author(s) 2018

\begin{abstract}
Recent public opinion research has established an empirical regularity of unusual stability and strength: citizen beliefs in the legitimacy of national and international institutions are highly linked. The dominant interpretation of this link holds that citizens draw on their perceptions of national institutions as a heuristic when forming opinions about international institutions. This article proposes an alternative mechanism, privileging social trust as an antecedent factor contributing to both national and international legitimacy beliefs. Using original survey data on citizen attitudes toward four international institutions in three countries, the article provides evidence for social trust as an antecedent factor, while granting no support for the dominant interpretation. The article suggests three broader implications: social trust has more far-reaching consequences for international cooperation than previously understood; political efforts to affect the legitimacy of international institutions are constrained by individual predispositions; and a comparative approach is central to the study of public attitudes toward international institutions.
\end{abstract}

Keywords Legitimacy · Social trust · International institution · Confidence $\cdot$ Political awareness

Electronic supplementary material The online version of this article (https://doi.org/10.1007/s11558-0189339-y) contains supplementary material, which is available to authorized users.

Lisa Maria Dellmuth

lisa.dellmuth@su.se

Jonas Tallberg

jonas.tallberg@statsvet.su.se

1 Department of Economic History and International Relations, Stockholm University, 10691 Stockholm, Sweden

2 Department of Political Science, Stockholm University, 10691 Stockholm, Sweden 


\section{Introduction}

Legitimacy in the eyes of the people may matter in profound ways for international institutions. If people widely believe that an international institution is lacking in legitimacy, this can affect its problem-solving effectiveness (Franck 1990; Dai 2005; Buchanan and Keohane 2006; Hurd 2007; Sommerer and Agné 2018). Similarly, if international institutions enjoy extensive power but lack legitimacy in society, this may contribute to a democratic deficit in global governance (Bodansky 1999; Held and Koenig-Archibugi 2005; Keohane 2011; Zürn 2018). Increasingly attentive to the potential importance of legitimacy for international institutions, International Relations (IR) scholars are beginning to systematically study its determinants, tracking longstanding efforts in comparative politics, political theory, and sociology to better understand the sources of legitimacy (Beetham 1991; Easton 1975; Suchman 1995; Weber [1922] 1978). ${ }^{1}$

This emerging literature has encountered an empirical regularity of unusual stability and strength: citizen beliefs in the legitimacy of national and international institutions are highly linked (Johnson 2011; Muñoz et al. 2011; Sattler and Urpelainen 2012; Harteveld et al. 2013; Voeten 2013; Armingeon and Ceka 2014; Chalmers and Dellmuth 2015; Dellmuth and Tallberg 2015; Schlipphak 2015; Ares et al. 2017). This finding is consistent across international institutions, time, alternative measures of legitimacy, and surveys. Moreover, it is substantively important: the perceived legitimacy of domestic institutions is usually the strongest predictor of an international institution's legitimacy, even when controlling for other relevant individual-level factors such as economic considerations, political awareness, and social identity.

However, existing research is hard-pressed to explain why national and international legitimacy beliefs are linked. Most studies stop at establishing this association, since their real purpose is to explain variation in international legitimacy beliefs. A few studies (Harteveld et al. 2013; Ares et al. 2017) have taken the additional step to theorize and empirically explore this link, but all are restricted to the European Union (EU), raising questions about the scope conditions of the arguments and their applicability to global governance more broadly. The dominant interpretation of the nationalinternational legitimacy link to date holds that citizens tend to know little about international institutions and therefore draw on their confidence in national political institutions as a heuristic when evaluating their international counterparts (Armingeon and Ceka 2014; Dellmuth and Tallberg 2015; Schlipphak 2015). Yet the evidence for this mechanism is mixed (Harteveld et al. 2013, 557, 562).

This article makes two central contributions toward a better understanding of the link between national and international legitimacy. First, we develop an alternative argument that privileges social trust as an antecedent factor shaping both national and international legitimacy beliefs, thereby contributing to the link between the two. Social trust, sometimes referred to as interpersonal or generalized trust, captures an individual's predisposition in terms of tending to trust other people or not (Hardin 2002;

\footnotetext{
${ }^{1}$ This article relies on a sociological understanding of legitimacy, where legitimacy is conceptualized as the perception or belief that an institution's authority is appropriately exercised (e.g., Caldeira and Gibson 1995; Hurd 2007; Weber [1922] 1978). This is different from a normative understanding, where an institution's legitimacy is derived from its conformance to philosophical values such as justice and democracy (Buchanan and Keohane 2006).
} 
Uslaner 2002). We argue that social trust affects people's general tendency to perceive of political institutions as legitimate by way of cooperative expectations (Brehm and Rahn 1997). People who are trusting tend to expect cooperative behavior from others, making them more likely to consider collective political institutions as legitimate. Conversely, people who lack social trust tend to question the intentions of others, making them less likely to consider collective political institutions as legitimate. If this mechanism is at work, the causal chain does not start with citizens' perceptions of the legitimacy of national institutions, but with their tendency to trust others, which in turn affects both national and international legitimacy beliefs.

Second, we offer the first comparative evaluation of these explanations, using data from an original survey of citizen attitudes toward four international institutions with varying issue-area orientation and membership scope: the EU, International Monetary Fund (IMF), United Nations (UN), and World Trade Organization (WTO). This selection allows us to examine the two explanations in institutional settings that extend beyond the conventional focus on the EU. The survey was conducted in three Western democracies: Germany, the United Kingdom (UK), and the United States (US). Focusing on stable democracies with similarities in economic development and power positions improves the equivalence of cross-national measures and reduces the potential impact of contextual factors beyond our interest. The survey was designed to enable a rigorous cross-institutional and cross-country assessment of the two explanations in the absence of suitable data from existing large-scale surveys. We examine the relationships between social trust, national legitimacy beliefs, and international legitimacy beliefs using structural equation modeling (SEM) and causal mediation analysis. This strategy allows us to overcome some of the most severe empirical problems in existing research by untangling the associations between these factors.

The central findings are two-fold. First, the evidence offers support for social trust as an antecedent factor, confirming several expectations consistent with this logic, while also indicating variation in explanatory fit across countries. Social trust tends to contribute to legitimacy beliefs vis-à-vis both national and international institutions. Moreover, a substantial part of the association between social trust and international legitimacy beliefs tends to be mediated through national legitimacy beliefs, corroborating the argument that social trust helps to account for the national-international legitimacy link. Comparing across countries, stronger associations between social trust and legitimacy beliefs go hand in hand with a stronger link between national and international legitimacy beliefs. Second, the results offer no support for the alternative expectation that heuristics drive the association between national and international legitimacy. Less politically aware people do not appear more likely to let their legitimacy beliefs toward international institutions be guided by their legitimacy beliefs toward national institutions, as this interpretation would suggest. These findings are robust also when using more comprehensive cross-national data from the World Values Survey (WVS) and the European Social Survey (ESS) for a restricted set of variables in the context of the UN and the EU.

Taken together, these findings suggest that social trust has more far-reaching implications than previously understood, that political efforts to affect the legitimacy of international institutions are constrained by individual predispositions, and that a comparative approach is important for the study of public opinion toward international institutions. 


\section{The domestic-international legitimacy link}

Recent years have seen the emergence of growing empirical literature on the legitimacy of international institutions. While not all of these works refer explicitly to "legitimacy," they all focus on measures often used to capture legitimacy beliefs, notably "trust" and "confidence" (see Dellmuth 2018 for an overview). A large part of this literature centers on attitudes toward the EU, but research on other international institutions is becoming increasingly common. Perhaps the most intriguing finding concerns the stable and strong association between national and international legitimacy beliefs. ${ }^{2}$

Muñoz et al. (2011), for instance, explore whether trust in national institutions fosters or hinders trust in the institutions of the EU. Existing research offers both expectations and this article aims to adjudicate the issue based on data from the European Social Survey for all EU member states for the period, 2004-2008. They find that trust in national parliaments contributes positively to trust in the European Parliament - and more so than any other factor.

Harteveld et al. (2013) arrive at similar results using Eurobarometer data for 2009 for all EU member states. They examine three explanations of trust in the EU: rational evaluations of the democracy and performance of the EU, territorial identity, and trust in domestic institutions. While they find support for all three explanations, trust in domestic institutions has by far the greatest impact. The predicted trust in the EU for a person with high trust in domestic institutions is 50\%age points higher than for a citizen with low trust in domestic institutions.

A third example from Europe is Armingeon and Ceka (2014), who seek to explain the decline in support for the EU during the recent economic recession. They analyze whether the drop in support is related to the EU's imposition of austerity reforms, the performance of the national economy, or trust in the national government. Using data from 133 national surveys in the 27 member states, they find that the drop in support for the EU is best explained by citizens' trust in national governments. All else equal, the probability of trusting the EU is 50 percent higher for citizens who trust their national government compared to those who do not.

Inspired by the strength and consistency of this finding in the European setting, several recent contributions examine the national-international legitimacy link for other international institutions. Schlipphak (2015) explores the determinants of public support for the African Union (AU) and the Union of South American Nations (UNASUR). He tests three alternative models, privileging economic gains, sociopsychological dynamics, and trust in domestic institutions, based on data from the Afrobarometer and Latinobarometer in 2009. In both regions, Schlipphak finds the strongest effects for trust in domestic institutions. Moving from the lowest to the highest category of the trust variable makes citizens two times more likely to express a positive evaluation of the regional organization.

\footnotetext{
${ }^{2}$ One is hard-pressed to find any study that includes measures of the legitimacy of domestic institutions in the analysis and does not report a strong, positive association with the legitimacy of international institutions. A few studies report a negative relationship between the performance of domestic institutions in a country and citizens' support for international institutions; however, the relationship between individual attitudes toward domestic and international institutions remains positive (Sánchez-Cuenca 2000; Kritzinger 2003; Muñoz et al. 2011).
} 
Exploring determinants of confidence in the UN, Dellmuth and Tallberg (2015) test the explanatory power of three models, focused on institutional performance, interest representation, and confidence in domestic institutions. Using WVS data from 1999 to 2001 on 26 countries worldwide, Dellmuth and Tallberg, too, find more support for confidence in domestic institutions than for any alternative explanation. Again, the association is substantively large: for a one-unit increase in their index of domestic confidence, the odds of more confidence in the UN increase by as much as $71 \%$.

A range of other contributions arrive at similar findings in different international settings. Johnson (2011) examines explanations of trust in the UN, WTO, and IMF, and finds that trust in the domestic government has the strongest effect of all. Sattler and Urpelainen (2012) demonstrate how government trust interacts with economic performance and treaty conditions to shape the likelihood of citizens voting yes or no to new EU treaties in national referenda. Voeten (2013) shows that trust in the European Court of Justice (in EU member states) and the International Criminal Court (in Uganda) first and foremost is associated with trust in domestic courts.

In sum, there is remarkable consistency across existing contributions: individuals' perception of the legitimacy of domestic institutions is a robust and strong - usually the strongest - predictor of their perception of the legitimacy of international institutions. This finding holds for different data sources and points in time. It is consistent across different types of national and international institutions. It is robust across multiple specifications of legitimacy: trust, support, and confidence.

What can explain this strong association between national and international legitimacy beliefs? In the following, we first introduce our novel explanation and a prominent alternative explanation.

\section{The argument: Social trust as an antecedent factor}

We suggest that the link between national and international legitimacy may be the result of a third factor - social trust - affecting both. Recent research interprets the link between national and international legitimacy as reflecting a common predisposition, "possibly an aspect of personality, general outlook on life or social standing" (Harteveld et al. 2013, 557). We pursue this possibility, systematically theorizing and assessing social trust as an antecedent factor. ${ }^{3}$ Our argument is not that the link between national and international legitimacy beliefs is spurious, but that this relationship is partly driven by a common mechanism.

We conceptualize social trust as an individual predisposition in terms of people's tendency to trust others. It is the "generalized expectancy held by an individual that the word, promise, oral or written statement of another individual or group can be relied on" (Rotter 1980, 1). Uslaner (2002) speaks of social trust as moralistic, because it derives from generalized moral judgments about the trustworthiness of others (see also Fukuyama 1995). Social trust varies across individuals, who are more or less generally

\footnotetext{
${ }^{3}$ While some earlier studies have included social trust as a control variable (Johnson 2011; Dellmuth and Tallberg 2015; Schlipphak 2015; Ares et al. 2017), it has not previously been systematically theorized and assessed as an explanation of the national-international legitimacy link.
} 
trusting of others, and whose trust may change during a lifetime. Social trust may also vary across societies, if some are composed of more trusting individuals than others.

Existing research identifies two main sources of social trust (Nannestad 2008; Newton and Zmerli 2011, 173; Uslaner 2018a). One model locates the sources of social trust at the individual level, with the socio-psychological dynamics of persons (Glanville and Paxton 2007). It claims that social trust is a core personality characteristic mainly learned early in life and linked to other psychological traits (Evans and Revelle 2008). Another model suggests that social trust is a product of larger social and political structures. Societies with dense networks of social relations and impartial political institutions lead individuals to develop higher levels of social trust, which in turn affects societies positively in a virtuous spiral (Putnam 1993; Rothstein and Stolle 2008). We consider it likely that social trust reflects both micro and macro sources, which makes it a relatively stable individual predisposition, while still open to slowmoving change and variation across societies. While the analysis takes individual's social trust as exogenously given, we also examine social trust as an endogenous variable, affected by the quality of domestic institutions, in the robustness checks.

Existing research indicates that social trust varies across countries, reflecting the influence of macro social and political structures (Nannestad 2008). Comparing across world regions, for instance, social trust is particularly high in Scandinavia and Oceania, and particularly low in Latin America and Sub-Saharan Africa (Mattes and Moreno 2018; see also Inglehart 1997). Comparing across political systems, social trust tends to be lower on average in newly democratizing countries than in established democracies, probably because of the influence of the prior authoritarian context on people's trust in each other (Jamal and Nooruddin 2010; Letki 2018). The general implication is a reminder that social trust and its effects are partly rooted in varying country-specific conditions (Uslaner 2018a).

Social trust is claimed to have positive effects on a number of social and political outcomes (Nannestad 2008; Uslaner 2018a). At the individual level, citizens who believe that most other people in society can be trusted are more inclined to be honest and altruistic (Fukuyama 1995), to support democratic institutions (Brehm and Rahn 1997), to participate more in politics (Putnam 2000), and to be more tolerant toward minorities (Uslaner 2002). At the societal level, countries, regions, or cities with more trusting people tend to have better working democratic institutions (Putnam 1993), to have greater economic equality (Rothstein and Uslaner 2005), and to be more willing to push for the creation of multilateral institutions (Rathbun 2011).

Extending this list of implications, we expect social trust to contribute to both national and international legitimacy beliefs. In this respect, we build on earlier research in comparative politics that has explored the effects of social trust on legitimacy beliefs. This literature has established a positive relationship between social trust and legitimacy beliefs at both the individual level (e.g., Brehm and Rahn 1997; Freitag and Bühlmann 2009; Newton and Zmerli 2011) and country level (Inglehart 1997; Newton and Norris 2000; Putnam et al. 2000, 26).

In line with important contributions to this literature, we assume the central mechanism linking social trust and legitimacy beliefs to be cooperative expectations (Brehm and Rahn 1997). In essence, people who are more trusting are more likely to expect cooperative behavior from other people, making it easier to have confidence in joint political institutions. This mechanism builds on a core component of the 
conceptualization of social trust - the generalized expectation that others can be trusted (Rotter 1980). ${ }^{4}$ As a "general outlook on human nature," social trust is associated with an expectation of cooperative behavior from others that is not dependent on personal experience or strategic information (Uslaner 2002: 17; Rathbun 2011). Whether people are trusting or not thus affects their general expectations on others in society, which in turn has consequences for collaborative outcomes and confidence in collective institutions (Brehm and Rahn 1997). People with a low degree of social trust will question the intentions of others, conceiving of them as potential cheaters from collective institutions. Conversely, people with a high degree of social trust will expect equally good intentions from others and not fear being taken advantage of within collective institutions. As a consequence, people with higher levels of social trust will be more willing to put their faith in joint political institutions at the national and international level.

The implication is that citizens' attitudes toward both national and international institutions are affected by a common antecedent factor - their general trust predisposition. This logic leads us to expect three empirical relationships. First, if this mechanism is at play, we would expect people's social trust to be positively associated with their beliefs in the legitimacy of both national and international institutions independent of each other. This is the most basic expectation from considering social trust as an antecedent factor. Second, we would expect people's social trust to affect their international legitimacy beliefs in two ways: while part of the effect would be direct, another part would be mediated through their national legitimacy beliefs, reflecting the impact of social trust on national legitimacy. This expectation extends logically from the first, taking into consideration how effects of social trust should manifest themselves in the relationship between national and international legitimacy. Third, in countries in which people's social trust is relatively strongly associated with their beliefs in the legitimacy of both national and international institutions, we would expect the association between national and international legitimacy beliefs to be relatively strong as well. This expectation recognizes that the positive effect of social trust on national and international legitimacy may not be equally strong in all countries, and draws out the implications of this possibility for the national-international legitimacy link. We take these expectations as the basis for three hypotheses:

Hypothesis 1: Social trust is positively associated with legitimacy beliefs toward both national and international institutions independent of each other.

Hypothesis 2: The positive association between social trust and international legitimacy beliefs is mediated through national legitimacy beliefs.

Hypothesis 3: In countries in which the positive associations between social trust and national and international legitimacy are strong, national and international legitimacy beliefs are strongly associated with each other as well.

\footnotetext{
$\overline{{ }^{4} \text { Social trust thus works differently }}$ than a cognitive heuristic, as conventionally understood. While heuristics are cognitive problem-solving strategies that individuals make use of to deal with information-processing demands (Lau and Redlawsk 2001: 952; Gigerenzer and Gaissmeier 2011: 454), social trust is an individual predisposition that shapes people's general outlook. Social trust affects thus legitimacy beliefs (or other outcomes) by being higher or lower for particular individuals - not by being more or less activated by individuals.
} 


\section{Alternative explanation: Political awareness}

In contrast to our explanation, the most common interpretation of the link between national and international legitimacy emphasizes citizens' political awareness. According to this logic, citizens who are poorly aware of politics use their legitimacy beliefs vis-à-vis national institutions as a heuristic when forming opinions about the legitimacy of international institutions, resulting in a close association between the two. In this context, political awareness means having a developed understanding of politics as a result of, for instance, news media consumption and discussion of politics among friends (Zaller 1992; Delli Carpini and Keeter 1996).

Contributions advancing this interpretation base their expectation on research about the quality of public opinion and the use of heuristics in attitude formation. Public opinion scholars have long argued that most citizens have low-quality opinions (Converse 1964; Zaller 1992), and therefore rely on cognitive heuristics to help them form attitudes toward political institutions (Mondak 2003; Chong and Druckman 2007). A heuristic is a cognitive problem-solving strategy (or mental shortcut) that allows an individual to ignore some information with the goal of making a decision more efficiently (Simon 1957; Kahneman et al. 1982; Gigerenzer and Gaissmaier 2011). Common heuristics used by citizens when forming opinions about political matters include elite communication and party identification (Green et al. 2002; Bullock 2011; Lau and Redlawsk 2001).

According to this interpretation, the link between national and international legitimacy is a result of citizens using their attitudes toward domestic institutions as such a heuristic. Citizens tend to have most developed attitudes toward the central political institutions at the national level. These are the institutions that feature most prominently in national news media and that citizens engage with through national elections. In comparison, international institutions are more distant, less well covered in news media, and less open for citizen engagement. Citizens therefore use their legitimacy beliefs toward the national institutions they know better as a heuristic when forming opinions about the international institutions they know less well. Expressed in the terms of the theoretical literature, citizens rely on a "representativeness heuristic," forming opinions about A based on its resemblance to B (Tversky and Kahneman 1974).

Existing research offers many examples of this interpretation. For instance, Armingeon and Ceka $(2014,82)$ conclude that "support for the EU is derived from evaluations of national politics and policy, which Europeans know far better than the remote political system of the EU." Similarly, Dellmuth and Tallberg $(2015,471)$ submit that "[f]or many citizens, IOs are complex and distant organizations, whose legitimacy is best approached via heuristics and cues derived from the more familiar national political context." This is also the interpretation favored by Schlipphak (2015, 367), who suggests that the national-international legitimacy link reflects "general satisfaction with or broad trust in domestic political actors that is extrapolated to a more diffuse trust of political actors operating at other levels beyond the national level." These contributions are inspired by earlier work in the EU context, showing that politically more aware citizens are more likely to base their assessments of democracy in the EU on the institution's procedures rather than other considerations (Karp et al. 2003). Yet, while common in existing literature, this interpretation still has to be confirmed empirically. The only systematic test so far finds mixed support for political 
awareness as an explanation of the national-international legitimacy link in the context of the EU (Harteveld et al. 2013, 557, 562).

We are skeptical of this alternative explanation on theoretical grounds and expect those weaknesses to be reflected in poor empirical explanatory power. In our reading, research on heuristics in social psychology offers limited support for the expectation that political awareness or knowledge dictates the use of heuristics. On the contrary, this literature tends to emphasize that all people rely on heuristics as mental shortcuts, but that the types of heuristics used and their effectiveness might vary with individual and contextual factors (Tversky and Kahneman 1974; Sniderman et al. 1991; Lau and Redlawsk 2001). Individuals generally have limited information processing capacity (Simon 1957) and are cognitive misers (Fiske and Taylor 1991), leading everyone to rely on information shortcuts. Political awareness per se does not make people less likely to rely on heuristics (Sniderman et al. 1991) and the politically more aware actually tend to use heuristics to better effect (Lau and Redlawsk 2001).

Yet, if we presume that political awareness is central, as claimed in this alternative interpretation, then the association between national and international legitimacy should be stronger among the politically unaware. Citizens with a higher level of political awareness should have more developed knowledge of international institutions, be better able to form judgments about these institutions, and therefore rely less on attitudes toward national institutions as a heuristic. This alternative explanation translates into the following hypothesis about an interaction effect between national legitimacy beliefs and political awareness on international legitimacy beliefs:

Hypothesis 4: The positive association between national and international legitimacy beliefs is stronger among less politically aware individuals.

\section{Research design}

To test these hypotheses, we collected novel data based on a public opinion survey conducted online in December 2014 and January 2015. An appropriate hypothesis test requires data that cover several international institutions and countries to allow for an examination of the scope of the argument, and that include measures of legitimacy beliefs, social trust, and central covariates such as political awareness, cosmopolitan identity, and national institutional satisfaction. Existing large-scale surveys fall short on one or both of these criteria. In particular, while the WVS would allow for analyses in the context of the EU and the UN, the data are old (third wave, 1999-2004) and do not include a continuous measure of social trust or a measure of national institutional satisfaction. ${ }^{5}$ Regional barometers, such as the Eurobarometer, Latinobarometer, and Afrobarometer, typically only cover attitudes toward a specific regional institution, and do not simultaneously include relevant covariates. The European Social Survey (ESS) measures legitimacy beliefs toward the European Parliament and the UN, but does not include important covariates (cosmopolitan identity, national institutional satisfaction) (Dellmuth 2018). To allow for a rigorous and comprehensive hypothesis test, we

\footnotetext{
5 The third wave of the WVS relies on a dichotomous measure of trust, which has been shown to be less reliable than trust indicators with an 11-point scale (Newton and Zmerli 2011).
} 
therefore designed our own cross-institutional and cross-country survey. In addition, we include robustness checks for the EU and the UN based on existing large-scale surveys using fewer control variables.

\subsection{Survey design}

Our survey covered four international institutions: EU, IMF, WTO, and UN. This selection ensures variation in issue-area orientation (finance, trade, and multi-issue) and membership scope (regional and global). Including the EU next to the global institutions allows us to explore if findings established in the European setting - the main focus of existing research - extend to other international institutions. Moreover, these are all institutions that possess extensive authority in their respective domains and are known to citizens in the member states at a basic level (cf., Gallup International Association 2012), making it meaningful to inquire about legitimacy beliefs.

We conducted the survey in three advanced Western democracies: Germany, the UK, and the US. Similarities across these countries in terms of democracy, economic development, and power positions in the international institutions help to reduce the potential impact of contextual factors beyond our immediate interest. In addition, focusing on stable democracies improves the equivalence of cross-national measures, since legitimacy for political institutions may mean different things to citizens of democracies and autocracies (Jamal 2007; Jamal and Nooruddin 2010). To probe the broader generalizability of our findings from these three countries, we also replicate the analysis using cross-national data from the WVS with a more restricted set of covariates.

Within these countries, samples were drawn from YouGov online panels. YouGov is a well-reputed global survey company frequently used by social scientists (Berinsky et al. 2012). ${ }^{6}$ It relies on targeted quota sampling with the aim to achieve representative samples at the end of the fieldwork. The samples for our survey were matched to the full populations of the four countries using age, education, gender, and party identification. ${ }^{7}$ A total of 657 interviews were conducted in Germany, 653 in the UK, and 628 in the US. ${ }^{8}$ To ensure that our analyses are based on nationally representative samples, we use survey weights for all analyses. ${ }^{9}$ Since all three countries have very high levels of Internet penetration (over $80 \%$ ), the online survey could reach respondents from all segments of the population, thereby increasing our confidence in the external validity of the findings.

\footnotetext{
${ }^{6}$ Moreover, prominent national surveys nowadays rely on YouGov, among them the British Election Study. ${ }^{7}$ See Ansolabehere and Schaffner (2014) on the sampling procedure for YouGov's online panels. In the US, an additional criterion was ethnicity.

${ }^{8}$ YouGov invited the target group to participate in the study through e-mail, informing the respondents about the length of the study and offering monetary incentives to participate. YouGov's incentive program is pointsbased. Point values are allocated upon survey completion and can be used either for participation in prize draws or for a cash payment. Those deciding to participate could access the survey through a link and answer the questions online.

${ }^{9}$ YouGov provides a design weight variable denoting the optimal weight that should be assigned to each observation to achieve nationally representative results.
} 


\subsection{Operationalization}

To operationalize the hypotheses, we created several measures. As we are interested in explaining the link between national and international legitimacy beliefs, we start by discussing the measurement of these two dependent variables. Legitimacy refers to a complex concept that is notoriously difficult to measure, and that may be too vague to understand for many survey respondents (Easton 1965: 169). Hence, previous literature commonly uses "confidence" as a measurement for individual beliefs in the legitimacy of political institutions (e.g., Caldeira and Gibson 1995; Inglehart 1997; Norris 2009; Bühlmann and Kunz 2011; Dellmuth and Tallberg 2015). This conceptualization of legitimacy beliefs is anchored in systems theory, which conceives of legitimacy as the reservoir of confidence in a political system, independent of short-term satisfaction with the distributional outcomes of the system (Easton 1975, 447). This conceptualization also suggests why "confidence" is a better measure than "support," as the latter can direct attention away from the underlying faith in a political system and toward satisfaction with short-term distributional consequences. In light of these considerations, we used questions about "how much confidence do you personally have" in the respective institutions (see Online Appendix A).

For the legitimacy of international institutions, we asked the respondents to indicate their confidence on a quasi-continuous scale from no confidence at all (0) to complete confidence (10). The question about confidence in the EU was only asked in Germany and the UK. The country-specific variation in confidence in international institutions is substantial (Fig. 1), underlining the value of a comparative design. To illustrate that confidence in international institutions varies considerably between and within countries, it is useful to depict mean confidence in international institutions across countries. Figure 1 shows that on average, the UN enjoys most legitimacy in all countries except the US, where the WTO enjoys about as much confidence. The WTO is the institution with the second-most confidence in all countries. The IMF enjoys less confidence than the EU in Germany, but more confidence than the EU in the UK. Comparing across countries, German respondents have most confidence in the UN and the WTO, while British respondents have most confidence in the IMF. American respondents consistently have least confidence in these international institutions.

We examined item non-response for this measure, as some citizens may know little or nothing about international institutions. ${ }^{10}$ About $92 \%$ of the respondents gave a substantive answer to the question about the UN and about $95 \%$ to the question about the EU, while roughly $77 \%$ indicated a confidence level for the IMF and the WTO. Although the frequency of the "don't know" answer is not a direct measure of political knowledge of these institutions (Mondak 1999), it gives an

\footnotetext{
$\overline{{ }^{10} \text { We test whether respondents' }}$ characteristics are correlated with item non-response, regressing a dummy variable $(1=$ response $)$ on age, gender, education, and fixed effects for international institutions. The coefficients of age, gender, and education are statistically significant and positive. However, as the dependent variable is relatively unequally distributed, we rely on effect sizes as well. Simulations changing the independent variables from their minimum to their maximum (cf. King et al. 2000) show that differences in response probabilities are about $2 \%$ for each of the three variables, which is an extremely small effect. We interpret this as an indication that our data is missing at random (see Rubin 1976).
} 


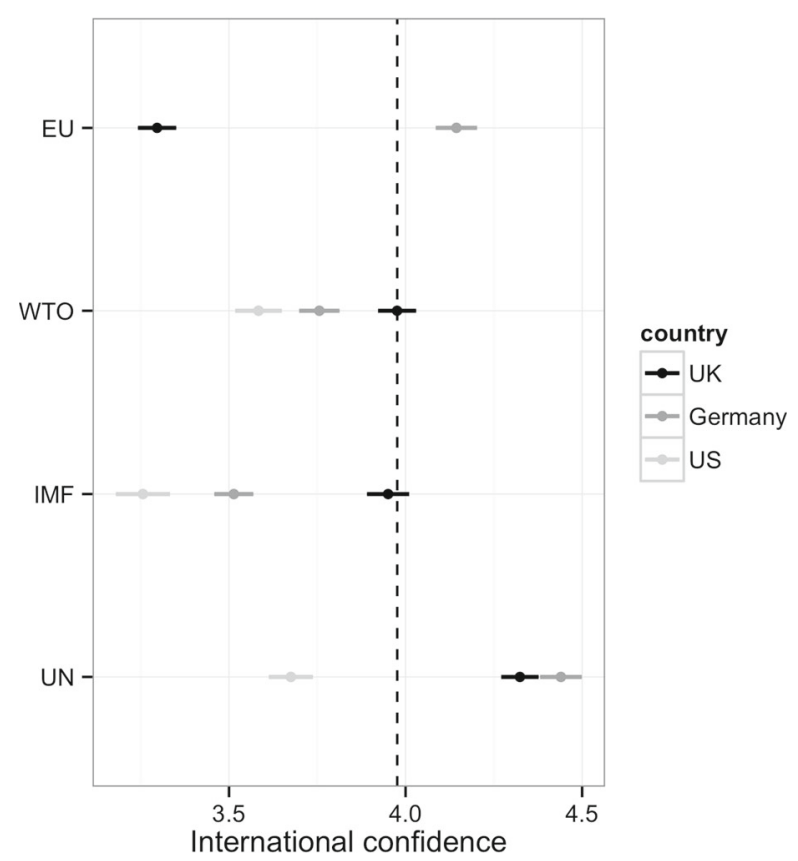

Notes: Weighted mean values with respective $95 \%$ confidence bounds, based on bootstrapped standard errors, calculated on the basis of a confidence question on a scale from 0 to 10 . Dotted line shows mean confidence across countries and institutions.

Fig. 1 Mean confidence in international institutions

indication of whether a respondent is well- or little informed. Hence, we draw the tentative conclusion that a large majority of respondents are familiar with these institutions, at least at a basic level. ${ }^{11}$

For the legitimacy of national institutions, we asked the respondents to indicate their confidence in their country's government on a scale from no confidence at all (0) to complete confidence (10). Confidence in national institutions varies between countries, with (weighted) mean confidence being 4.24 in the UK, 4.37 in Germany, and 3.72 in the US.

Next, we discuss the measurement of the independent variables. Inspired by the European Social Survey (2014) and recent scholarship (Newton and Zmerli 2011), we measure social trust based on the question "Generally speaking, would you say that most people can be trusted, or that you can't be too careful in dealing with people?", where respondents could indicate a number on the 11-point scale ranging from "most people can be trusted" (10) to "you can't be too careful" (0). This measure captures the extent to which people trust each other and people they do not personally know (Brehm and Rahn 1997). This question was not asked in immediate connection with the confidence questions in the survey to decrease the risk of question order effects (see Online Appendix A).

For political awareness, we use two commonly employed measures. The first measure taps political interest based on a question about the frequency with which

$\overline{{ }^{11} \text { Gallup International Association }}$ (2012) reports similar results. 
respondents discuss politics with friends: "frequently" (3), "occasionally" (2) or "never" (1). It is based on the assumption that individuals who talk about politics more frequently are more likely to have developed skills to comprehend new political information (Gabel and Scheve 2007). Second, we include a variable media exposure capturing whether people follow different news media "frequently" (3) to "occasionally" (2) to "never" (1).

In addition, we include several controls that previous literature suggests may be related to national or international confidence. To begin with, we include variables tapping satisfaction with national institutions to investigate whether this shapes confidence in national and international institutions (Torgler 2008; Zmerli 2010). Performance satisfaction measures whether a person agrees (1) or disagrees (0) that their government is doing a good job. Democracy satisfaction captures whether a person agrees (1) or disagrees ( 0$)$ that their government's decisions are democratic.

We also control for cosmopolitan identity, which has been shown to influence people's attitudes toward a range of international issues (Norris 2000; Ecker-Ehrhardt 2016). We use a question about territorial identity (Hooghe and Marks 2005), where people could rank-order whether they identify most with the world, their world region, their country, or their subnational territory. Cosmopolitan identity is coded 0 if people rank either their subnational or national territory first or second, and 1 if people rank either the world or their world region first or second.

Education has been shown to affect attitudes toward European integration independent of political awareness (Gabel 1998; Gabel and Scheve 2007; Dellmuth and Chalmers 2017), which is why we do not add it to the list of measures of political awareness. Rather, we include education as an indicator of human capital (cf. Gabel and Scheve 2007). The measure is based on country-specific variables on a four-point scale, ranging from "no formal qualifications or primary school" (1), "secondary education" (2), and "post-secondary non-tertiary education" (3) to "tertiary education" (4).

Finally, we control for gender as a dichotomous measure ( $1=$ female), as women have been shown to have less supportive attitudes toward international institutions (Gabel and Scheve 2007; Dellmuth and Chalmers 2017), and age as a continuous variable, as younger people may be more cosmopolitan and therefore more likely to perceive international institutions as a good thing (Inglehart and Rabier 1978; Torgler 2008; Dellmuth and Chalmers 2017) (see Online Appendix B for descriptive statistics and bivariate correlations between all variables introduced in this section).

\subsection{Model specification}

We examine the hypotheses through linear structural equation modeling (SEM) and causal mediation analysis. While the advantages and disadvantages of SEM have been intensely debated in the existing public opinion literature (Bollen and Pearl 2013), this technique is appropriate to evaluate our hypotheses for two main reasons. First, it allows for estimating complex relationships between cognitive variables as hypothesized above. Specifically, it allows us to estimate two equations simultaneously - one where international confidence is the dependent variable and social trust the main independent variable of interest, and one where national confidence is the dependent variable and social trust the main independent variable of interest. We use SEM 
analysis to interpret models on the basis of our causal assumptions, and examine estimates of statistical associations between variables that we interpret in the light of theory (cf. Bollen 1989: chapter 3). Second, the SEM approach can be understood within the framework of causal inference based on the procedures described in Imai et al. (2010, 2011), which enables us to test H2 predicting a mediating effect.

The following generic equations operationalize the hypotheses and are the basis for a so-called mediation model:

$$
\begin{gathered}
\mathrm{Y}_{i}=\beta_{i 0}+\gamma^{\prime} \mathrm{X}_{i}+\beta_{1} \mathrm{M}_{i}+\xi_{w} \boldsymbol{W}_{i 2}+\varepsilon_{i 2} \\
\mathrm{M}_{i}=\alpha_{i 0}+\alpha_{1} \mathrm{X}_{i}+\xi_{v} \boldsymbol{V}_{i 1}+\varepsilon_{i 1}
\end{gathered}
$$

$\mathrm{Y}_{i}$ refers to international confidence for each respondent $i, \mathrm{X}$ to social trust, $\mathrm{M}$ to national confidence, and $\boldsymbol{V}$ as well as $\boldsymbol{W}$ to vectors for individual-level controls. $\alpha_{0}$ and $\beta_{0}$ are intercept terms and $\varepsilon$ refers to a regression residual. By moving $M$ to the left side of the equation in Eq. 2, we are able to estimate simultaneously whether social trust is an antecedent factor of both national and international confidence ( $\mathrm{H} 1$ and $\mathrm{H} 3$ ). To test $\mathrm{H} 4, \boldsymbol{W}$ includes the product term between political awareness and national confidence. $\alpha_{0}$ and $\beta_{0}$ are intercept terms. $\varepsilon_{i 1}$ and $\varepsilon_{i 2}$ refer to regression residuals, assuming $(\mathrm{E}[\varepsilon \mid X]=0)$.

$\mathrm{H} 2$ is different from the other hypotheses in that it requires testing for a mediating effect of national confidence on the relationship between social trust and international confidence. This involves estimating the proportion of the effect of social trust on international confidence that runs through national confidence, and the proportion of the effect of social trust that affects international confidence directly. For this purpose, we conduct a causal mediation analysis, which makes use of the SEM approach within the framework of causal inference based on counterfactual-based definitions of "direct" and "causal mediation" effects (Imai et al. 2010, 2011). In this framework, $\mathrm{Y}_{i}(x, m)$ is used to denote the potential outcome that would result if the independent (social trust) and mediating (national confidence) variables equal $x$ and $m$, respectively. The SEM analysis estimating Eqs. 1 and 2 thus yields an average causal mediation effect (ACME) calculated as the average effect among all people in the population of which the sample of respondents $i$ can be considered as representative:

$$
\delta_{i}(\mathrm{x}) \equiv \mathbb{E}\left\{\mathrm{Y}_{i}\left(x, \mathrm{M}_{i}(10)\right)-\mathrm{Y}_{i}\left(x, \mathrm{M}_{i}(0)\right)\right\}
$$

where the independent variable $x$ - social trust - runs from its minimum to its maximum value $[0,10]$ and the mediator - national confidence - has potential values from 0 to 10. Similarly, averaging the direct association between M and Y across all people in the total population yields the average direct effect (ADE). This direct 
effect is defined in terms of specific values of the mediator rather than its potential values $\mathrm{M}_{i}(10)$ or $\mathrm{M}_{i}(0)$ :

$$
\zeta_{i}(x) \equiv \mathbb{E}\left\{\mathrm{Y}_{i}\left(10, \mathrm{M}_{i}(x)\right)-\mathrm{Y}_{i}\left(0, \mathrm{M}_{i}(x)\right)\right\}, \text { for } x=[0,10]
$$

Finally, the total effect of social trust on international confidence when national confidence is held constant is the sum of the ACME and the ADE:

$$
\tau_{i}=\mathbb{E}\left\{\delta_{i}(x)+\zeta \mathrm{i}(1-x)\right\}
$$

\section{Results and discussion}

This section presents and discusses the results from the hypothesis tests. We begin by exploring the bivariate correlations between confidence in national and international institutions, and then proceed by testing the hypotheses and the robustness of the presented results.

\subsection{Bivariate correlations}

As could be expected from the strong and robust association between national and international legitimacy in previous research, the two confidence measures are

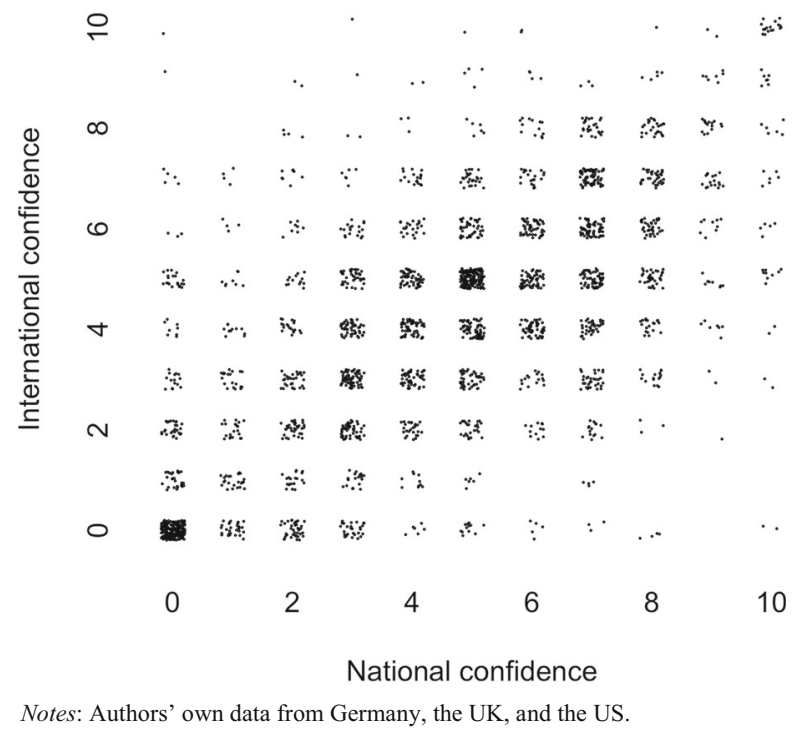

Fig. 2 Correlation between confidence measures 
moderately highly correlated ( $r=0.514, p=0.000, N=6076$, Fig. 2 ). We depict this correlation in Fig. 2 to give a visual impression of this correlation. The figure shows that people who have high (low) confidence in national institutions also tend to have high (low) confidence in international institutions, even if the spread of observations across all values of the two confidence variables indicates that other combinations exist as well.

Table 1 reports the correlation between national and international confidence by institutions and countries. It suggests three conclusions. First, the correlation is statistically significant for all three country samples in relation to all four international institutions, underlining the general character of this association. Second, there is limited variation in the strength of the correlation across different international institutions, both in the aggregate and within individual countries. Third, there is notable cross-country variation, resulting from a considerably weaker correlation between national and international confidence in the UK compared to Germany and the US. Unsurprisingly, given the Brexit vote in 2016, the disconnect in the UK between confidence in national and international institutions is strongest in relation to the EU. However, this pattern partly extends to the other institutions as well, suggesting that the link between national and international legitimacy generally may be weaker in the UK than elsewhere.

These patterns are underlined by a SEM analysis in which we pool observations on all four international institutions. For all countries combined, a one-unit increase in confidence in government is associated with an increase of 0.39 on the confidence in international institutions scale (Model 1 in Table 2). Confidence in national institutions is statistically significant throughout, even if the association is weaker in the UK (Models 2-4 in Table 2).

\subsection{Hypothesis tests}

We test the generic hypotheses on the basis of Eqs. 1 and 2 using pooled data on all four international institutions, but report robustness checks with fixed effects showing that the results do not differ when taking, potentially unobserved institutional characteristics into account. In the regression Tables 2 and 3, we present results using pooled data with country fixed effects and then models for countries separately, as our argument is based

Table 1 Bivariate correlations between national and international confidence

\begin{tabular}{lllll}
\hline & All & UK & Germany & US \\
\hline EU & $0.412^{*}(1245)$ & $0.117 *(624)$ & $0.693^{*}(621)$ & Not asked $^{\mathrm{a}}$ \\
IMF & $0.569^{*}(1544)$ & $0.349 *(507)$ & $0.673 *(584)$ & $0.667 *(453)$ \\
UN & $0.527 *(1773)$ & $0.289^{*}(599)$ & $0.626^{*}(606)$ & $0.639^{*}(568)$ \\
WTO & $0.543^{*}(1514)$ & $0.347 *(471)$ & $0.638^{*}(559)$ & $0.603 *(484)$ \\
All institutions & $0.514^{*}(6076)$ & $0.259^{*}(2201)$ & $0.653^{*}(2370)$ & $0.635^{*}(1505)$ \\
\hline
\end{tabular}

Pearson's $r$, with number of observations in parentheses. $* p>0.05$. ${ }^{a}$ The questions about confidence in the EU was not asked in the US, as it would not have been equivalent to the other data, where questions about international institutions were only asked in these institutions' member states 
Table 2 Structural equation models of national and international confidence

\begin{tabular}{|c|c|c|c|c|}
\hline Parameter estimate & $\begin{array}{l}\text { Model } 1 \\
\text { All countries }\end{array}$ & $\begin{array}{l}\text { Model } 2 \\
\text { UK }\end{array}$ & $\begin{array}{l}\text { Model } 3 \\
\text { Germany }\end{array}$ & $\begin{array}{l}\text { Model } 4 \\
\text { US }\end{array}$ \\
\hline \multicolumn{5}{|c|}{ International confidence (Eq. (1)) } \\
\hline National confidence & $\begin{array}{l}0.39 * * * \\
(0.03)\end{array}$ & $\begin{array}{l}0.19^{* * * *} \\
(0.06)\end{array}$ & $\begin{array}{l}0.49 * * * \\
(0.04)\end{array}$ & $\begin{array}{l}0.57 \text { *** } \\
(0.05)\end{array}$ \\
\hline Social trust & $\begin{array}{l}0.14 * * * \\
(0.02)\end{array}$ & $\begin{array}{l}0.20^{* * *} \\
(0.04)\end{array}$ & $\begin{array}{l}0.10^{* * *} \\
(0.03)\end{array}$ & $\begin{array}{l}-0.03 \\
(0.04)\end{array}$ \\
\hline Cosmopolitan identity & $\begin{array}{l}0.32^{* * * *} \\
(0.07)\end{array}$ & $\begin{array}{l}0.11 \\
(0.14)\end{array}$ & $\begin{array}{l}0.24 * * \\
(0.09)\end{array}$ & $\begin{array}{l}0.44 * * * \\
(0.12)\end{array}$ \\
\hline Performance satisfaction & $\begin{array}{l}0.29^{*} \\
(0.13)\end{array}$ & $\begin{array}{l}0.56^{*} \\
(0.22)\end{array}$ & $\begin{array}{l}0.28 \\
(0.18)\end{array}$ & $\begin{array}{l}0.03 \\
(0.21)\end{array}$ \\
\hline Democracy satisfaction & $\begin{array}{l}0.18 \\
(0.14)\end{array}$ & $\begin{array}{l}-0.33 \\
(0.27)\end{array}$ & $\begin{array}{l}0.28 \\
(0.19)\end{array}$ & $\begin{array}{l}0.86^{* * *} \\
(0.24)\end{array}$ \\
\hline Political interest & $\begin{array}{l}0.05 \\
(0.07)\end{array}$ & $\begin{array}{l}-0.05 \\
(0.11)\end{array}$ & $\begin{array}{l}0.06 \\
(0.10)\end{array}$ & $\begin{array}{l}0.19 \\
(0.13)\end{array}$ \\
\hline Media exposure & $\begin{array}{l}-0.10 \\
(0.10)\end{array}$ & $\begin{array}{l}-0.24 \\
(0.19)\end{array}$ & $\begin{array}{l}0.32 * \\
(0.14)\end{array}$ & $\begin{array}{l}-0.26 \\
(0.16)\end{array}$ \\
\hline Age & $\begin{array}{l}-0.01 * * * \\
(0.00)\end{array}$ & $\begin{array}{l}-0.00 \\
(0.01)\end{array}$ & $\begin{array}{l}-0.02^{* * * *} \\
(0.00)\end{array}$ & $\begin{array}{l}-0.03^{* * *} \\
(0.01)\end{array}$ \\
\hline Gender & $\begin{array}{l}0.20 * \\
(0.10)\end{array}$ & $\begin{array}{l}-0.04 \\
(0.16)\end{array}$ & $\begin{array}{l}0.13 \\
(0.12)\end{array}$ & $\begin{array}{l}0.52 * * \\
(0.19)\end{array}$ \\
\hline Education & $\begin{array}{l}-0.02 \\
(0.06)\end{array}$ & $\begin{array}{l}0.03 \\
(0.08)\end{array}$ & $\begin{array}{l}0.11 \\
(0.10)\end{array}$ & $\begin{array}{l}-0.06 \\
(0.10)\end{array}$ \\
\hline \multicolumn{4}{|l|}{ National confidence (Eq. (2)) } & No \\
\hline Social trust & $\begin{array}{l}0.14 * * * \\
(0.03)\end{array}$ & $\begin{array}{l}0.05 \\
(0.03)\end{array}$ & $\begin{array}{l}0.19 * * * \\
(0.03)\end{array}$ & $\begin{array}{l}0.23 * * \\
(0.09)\end{array}$ \\
\hline Performance satisfaction & $\begin{array}{l}1.53^{* * *} \\
(0.13)\end{array}$ & $\begin{array}{l}1.73^{* * *} \\
(0.18)\end{array}$ & $\begin{array}{l}1.91 * * * \\
(0.17)\end{array}$ & $\begin{array}{l}0.56 \\
(0.33)\end{array}$ \\
\hline Democracy satisfaction & $\begin{array}{l}2.85^{* * * *} \\
(0.14)\end{array}$ & $\begin{array}{l}3.27 * * * \\
(0.18)\end{array}$ & $\begin{array}{l}2.64 * * * \\
(0.17)\end{array}$ & $\begin{array}{l}2.28 * * * \\
(0.40)\end{array}$ \\
\hline Political interest & $\begin{array}{l}-0.01 \\
(0.11)\end{array}$ & $\begin{array}{l}-0.00 \\
(0.11)\end{array}$ & $\begin{array}{l}0.04 \\
(0.12)\end{array}$ & $\begin{array}{l}-0.04 \\
(0.28)\end{array}$ \\
\hline Media exposure & $\begin{array}{l}0.44 \\
(0.23)\end{array}$ & $\begin{array}{l}0.53^{* * *} \\
(0.19)\end{array}$ & $\begin{array}{l}0.13 \\
(0.17)\end{array}$ & $\begin{array}{l}0.59 \\
(0.54)\end{array}$ \\
\hline Age & $\begin{array}{l}0.00 \\
(0.00)\end{array}$ & $\begin{array}{l}-0.00 \\
(0.01)\end{array}$ & $\begin{array}{l}0.00 \\
(0.01)\end{array}$ & $\begin{array}{l}-0.00 \\
(0.01)\end{array}$ \\
\hline Gender & $\begin{array}{l}0.03 \\
(0.12)\end{array}$ & $\begin{array}{l}0.24 \\
(0.15)\end{array}$ & $\begin{array}{l}-0.14 \\
(0.14)\end{array}$ & $\begin{array}{l}0.09 \\
(0.33)\end{array}$ \\
\hline Education & $\begin{array}{l}0.18^{*} \\
(0.08)\end{array}$ & $\begin{array}{l}0.18^{*} \\
(0.09)\end{array}$ & $\begin{array}{l}-0.04 \\
(0.11)\end{array}$ & $\begin{array}{l}0.27 \\
(0.21)\end{array}$ \\
\hline Country fixed effects & Yes & No & No & No \\
\hline Overall $R$-squared & $58.79 \%$ & $68.31 \%$ & $66.95 \%$ & $43.37 \%$ \\
\hline$N$ & 5470 & 1933 & 2176 & 1361 \\
\hline
\end{tabular}

Structural equation analysis using design weights. Unstandardized coefficients, with standard errors in parentheses. $* p<.05, * * p<.01, * * * p<.001$. A constant is included in each equation, but not reported here 
on the premise that social trust partly is rooted in different country-specific institutional contexts, implying that there may be country-specific results worth considering.

The evidence in most models suggests that social trust is positively associated with legitimacy beliefs toward both national and international institutions, which supports H1 (Table 2). Pooling observations from all three countries, a one-unit increase in social trust is associated with a close to $15 \%$ increase in confidence in both national and international institutions (Model 1). However, while disaggregating by country reveals a pattern that is broadly conformant with this picture, it also involves some variation that runs counter to H1. Social trust is associated with international confidence in Germany and the UK, but not in the US. The US exception may reflect the fact that American respondents on average have a very skeptical attitude toward international institutions (see Fig. 1). Similarly, social trust is associated with national confidence in Germany and the US, but not in the UK (Models 2-4), which we discuss further below.

With regard to $\mathrm{H} 2$, we find ample support for the expectation that the association between national and international confidence is partially due to the antecedent factor of social trust. A causal mediation analysis estimating Eqs. 3-5 evaluates whether the association between social trust and international confidence is mediated by national confidence. If a part of the association between social trust and international confidence is mediated by national confidence, this would indicate that this part of the correlation between national and international confidence is due to the indirect mechanism operating through social trust. Conversely, if no part of the association between social trust and international confidence is mediated by national confidence, this would indicate that social trust may shape both national and international confidence but may not account for the correlation between national and international confidence.

Indeed, while the results indicate that part of the association is due to the ADE (see Eq. 4) of social trust on international confidence, about $30 \%$ of the association between social trust and international confidence is mediated by or goes through national confidence when pooling observations across countries, as indicated by the ACME (see Eq. 3) of national confidence. We depict three different average effects in Fig. 3, corresponding to the three effects formalized in Eqs. 3-5 (i.e., the ADE, ACME, and the total effect). The magnitude of these average effects can be understood against the background of the 11-point confidence scale (see Online Appendix A).

Thus, the results from the causal mediation analysis suggest that, on average, the association between national and international confidence is to a considerable degree due to variation in social trust as an antecedent factor, thereby supporting H2. ${ }^{12}$ Disaggregating by country, the association between social trust and international confidence is significant throughout, whereas the proportion of this association that is mediated through national confidence varies substantially across countries. In the US, as much as $70 \%$ of the association between social trust and international confidence is mediated through national confidence. In Germany, the proportion mediated is $51 \%$. By contrast, the proportion mediated is only $6 \%$ in the UK. While the results in Germany and the US thus corroborate our argument, the UK diverges from this pattern and does not show strong evidence of $\mathrm{H} 2$.

\footnotetext{
${ }^{12}$ We test $\mathrm{H} 2$ by evaluating the sampling distribution of the effects through bootstrapping and then using the information from the bootstrap sampling distribution to generate confidence intervals for the conditional indirect effect (cf. Preacher et al. 2007).
} 


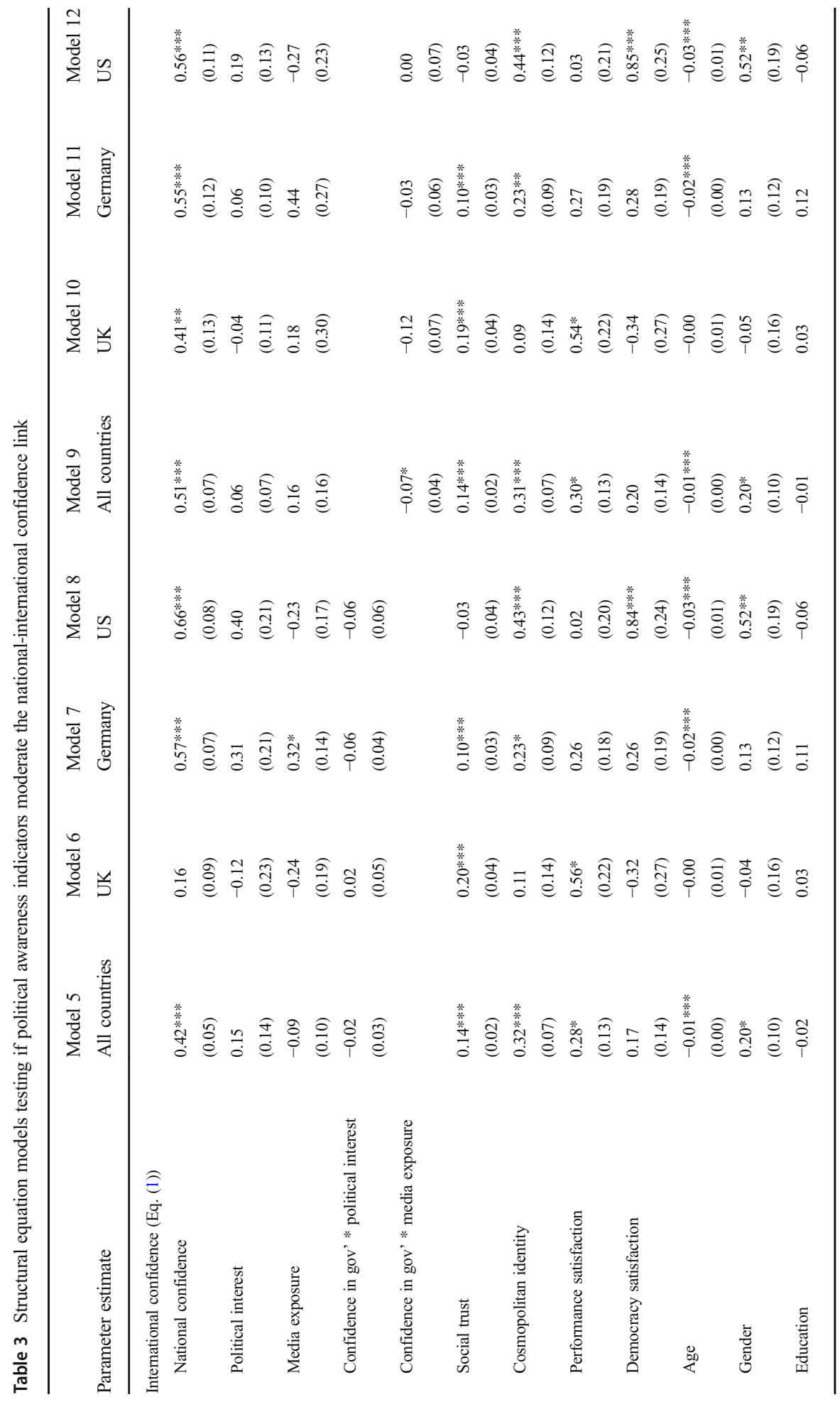




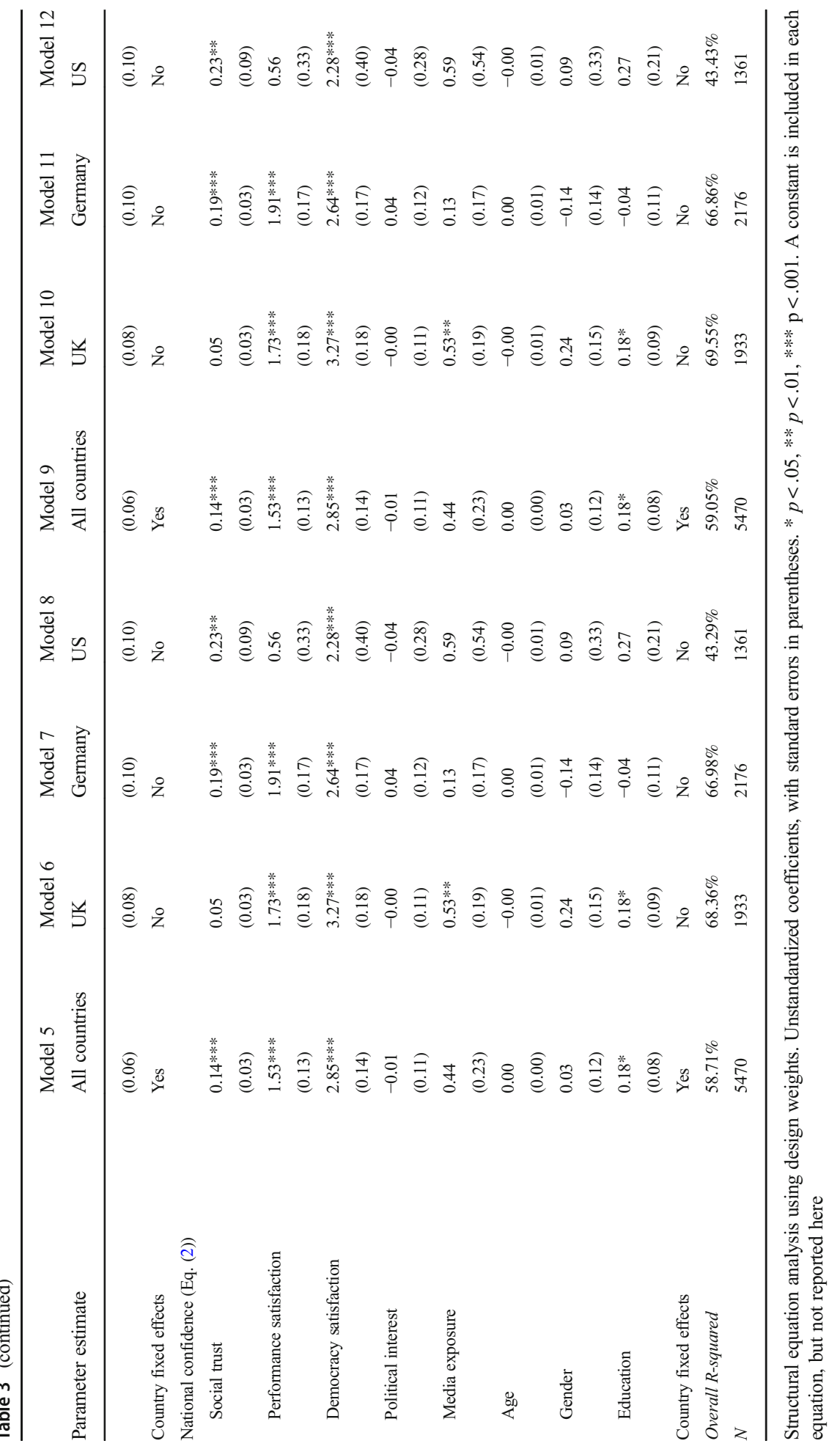



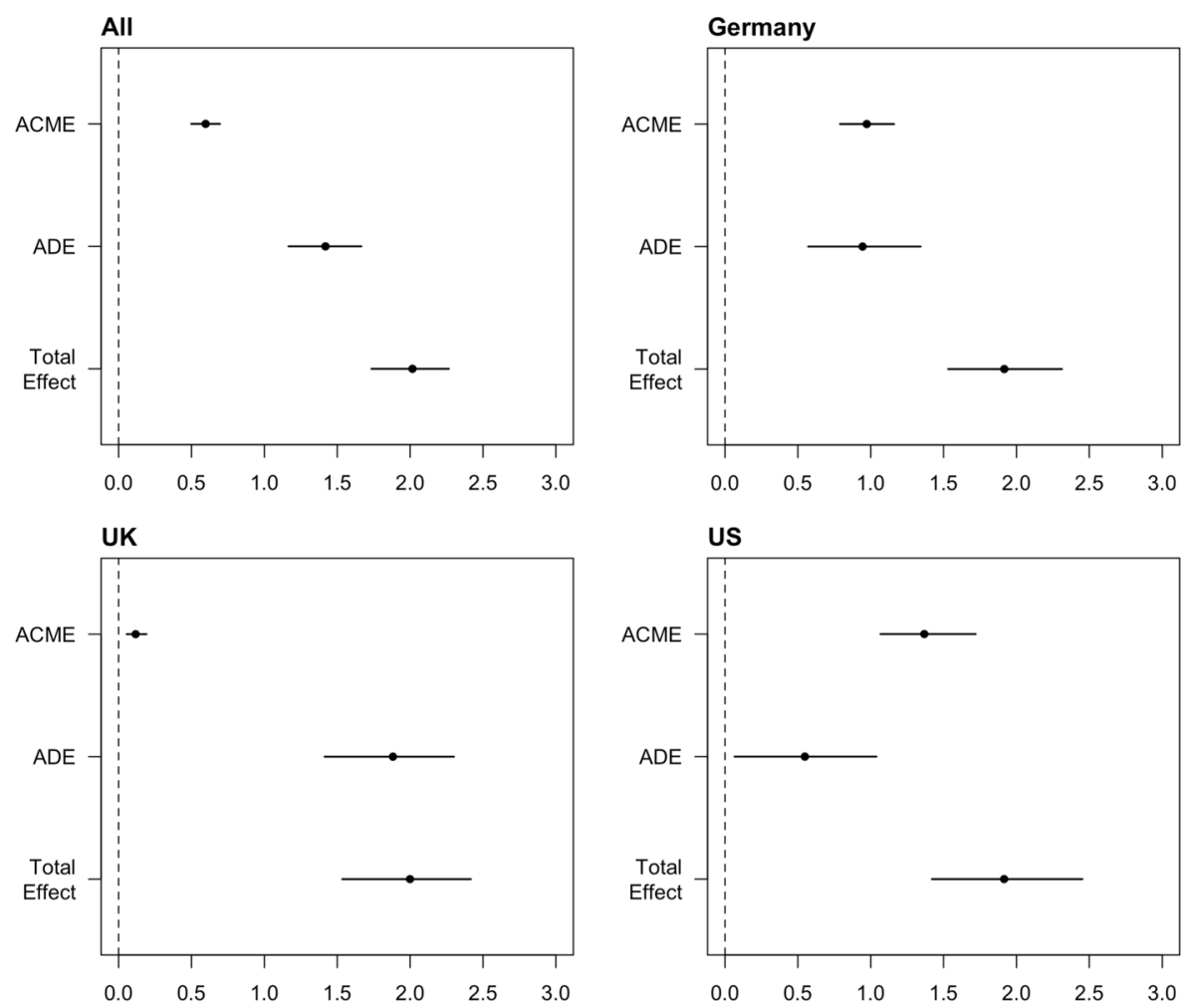

Notes: Estimations of Eqs. 3-5. The dots in the figures depict weighted

estimates and their respective $95 \%$ confidence bounds, based on bootstrapped standard errors. The proportion mediated averaged across the three countries is $30 \%$, in Germany $51 \%$, in the UK $6 \%$, and in the US $70 \%$ (rounded percentages). In the language of causal mediation analysis, the 'total effect' equals the sum of the $\mathrm{ACME}$ and the $\mathrm{ADE}$ (see Eq. 5). The proportion mediated is calculated by taking the ratio of the indirect to the total effect (see Online Appendix C for numerical results and sample sizes)

Fig. 3 Causal mediation analysis

The results for the UK raise the question of why social trust does not account for the link between national and international confidence in this case. While the data were gathered at the end of 2014 and the beginning of 2015, 18 months before the "Brexit" referendum, Brits already were increasingly dissatisfied with both domestic and EU politics, which may have shaped the results. At that time, Brits were exceptionally unsatisfied with the government coalition between the Tories and the Liberal Democrats. According to the British Social Attitudes survey, confidence in the government was at a historical low, with only $17 \%$ of the population indicating that they had confidence in government, which is less than half the figure recorded in $1986 .{ }^{13}$ This dynamic may help to understand why social trust is associated with international confidence but not national confidence (Table 2), which in turn would help to explain why social trust is not associated with national confidence in the UK

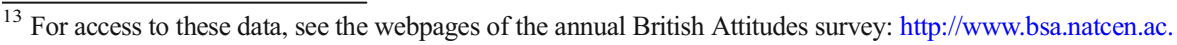
uk.
} 
(Models 2-4), and why the results for the UK in Fig. 3 do not show evidence of a mediating role of national confidence.

The bivariate correlations (Table 1) and the regression analyses (Table 2) also allow us to evaluate $\mathrm{H} 3$. The results corroborate our expectation: where the link between national and international confidence is strong (Germany, US), social trust has been at play; where the link is weak (UK), social trust does not matter. Put differently, a weak (or strong) association between social trust and national and international confidence, respectively, means a weak (or strong) association between the two confidence measures.

Taken together, these results underline the status of social trust as an antecedent factor helping to explain the link between confidence in national and international institutions.

Next, we examine H4 by estimating Eqs. 1 and 2, expressing the expectation of the alternative explanation. The results do not suggest that political awareness moderates the national-international confidence link (Table 3). The interaction terms for both measures of political awareness, political interest and media exposure, are insignificant in both the pooled and country-specific analyses, indicating that less politically aware people are not more likely to use their legitimacy beliefs toward national institutions as a heuristic when forming opinions about international institutions.

\subsection{Robustness checks}

These results are robust across a range of alternative model specifications and data sets. First, we are interested in knowing if the results in Eq. 2 hold if we control for a potential effect of international on national confidence in Eq. 2. While an effect of international on national confidence is not in itself problematic for our argument, as we seek to explain the association between the two, it could potentially affect our findings on social trust and political awareness. The analysis indicates that international confidence has a statistically significant effect in the pooled sample and in the models for Germany and the US. However, all our results remain robust (Online Appendix D1).

Second, we investigate whether social trust may be affected by people's perceptions of the quality of domestic political institutions, which is a prominent argument in the literature on the determinants of social trust (Brehm and Rahn 1997; Rothstein and Stolle 2008). We replicate all models by testing for independent effects on social trust of satisfaction with government performance and democracy. While our results on the effects of social trust remain unchanged, the more interesting finding pertains to the sources of social trust. It appears that in Germany and the UK, social trust is shaped by people's satisfaction with government performance, but not government democracy. This finding corroborates our starting assumption that social trust is anchored in both personality characteristics and political structures, making it relatively stable, but still open to slowmoving change (Online Appendix D2).

Third, we replicate Table 2 by including fixed effects for international institutions to check if potentially unobserved institutional characteristics may drive our results. We do not find evidence that this is the case (Online Appendix D3). This indicates that our principal findings hold across all four international institutions.

Fourth, we test whether our results hold using a restricted set of covariates in the context of the EU and the UN on the basis of WVS data. While these data (and alternative regional surveys) are less optimal for our purposes, which was why we constructed our 
own survey, they offer the possibility of a robustness check in a broader sample of countries. Such a test is only possible using data for the UN and the EU from the third wave of the WVS (1999-2004). Data on the UN are available for 47 countries worldwide, and data for the EU for eight EU member states. The replication of Table 2 vouches for the robustness of our results. ${ }^{14}$ The social trust hypothesis receives support in relation to both the UN and the EU. Social trust predicts both national and international confidence. In addition, social trust moderates the relationship between national and international confidence, although not as visibly as in the analysis of our sample. The political awareness hypothesis receives mixed support. While some coefficients of the interaction terms testing for a moderating effect of different awareness indicators are statistically significant, plotting these terms reveals moderating effects to be extremely small (Tables D4-D7, Figures D1-D3). ${ }^{15}$

\section{Conclusion}

While a large number of studies have found a strong association between national and international legitimacy beliefs, the mechanisms behind this link have remained poorly understood. Many have speculated that poor awareness of international institutions leads citizens to rely on domestic heuristics, but this interpretation has performed badly when tested empirically. Others have suggested that there may be some common source driving both national and international legitimacy, but not examined what that might be.

In this article, we have addressed this gap by developing a novel argument about social trust as an antecedent factor contributing to both national and international legitimacy beliefs, thereby helping to explain the link between the two. We have empirically evaluated this argument and the alternative explanation emphasizing political awareness using data from an original survey of citizen attitudes toward four international institutions in three countries. The results largely corroborate our argument, showing extensive support for social trust as an antecedent factor in the pooled analysis, in Germany, and in the US, as well as moderate support in the UK. The findings yield no support for the alternative explanation. These results are consistent across a range of model specifications and replications accounting for potentially unobserved characteristics of international institutions, indicating that these findings capture general dynamics in global governance. While we cannot assume that these results from three Western, democratic countries automatically extend to all countries, our replications of the analysis using existing crossnational data on 47 diverse countries with a restricted set of covariates suggest they may have broader generalizability.

The broader implications are threefold. First, our results suggest that social trust has wider political consequences than previously assumed. Research in comparative politics

\footnotetext{
${ }^{14}$ See Tables F5 and F6, where we also document the operationalization of variables used in these analyses. It is important to note that these analyses do not include indicators for satisfaction with government democracy and performance. Moreover, they rely on a dichotomous measure of trust, which has been shown to be less reliable than trust indicators with an 11-point scale (Newton and Zmerli 2011).

${ }^{15}$ We find similar results using ESS data for both the UN and the European Parliament, which we use as a proxy for the EU (see Tables F7-F8, Figures F4-F9, for results and a documentation of the operationalization for these analyses).
} 
indicates that social trust is beneficial for civic mobilization (Putnam 2000), attitudes toward democracy (Newton and Zmerli 2008), tolerance against minorities (Uslaner 2002), government performance (Zak and Knack 2001), economic growth (Fukuyama 1995), and other outcomes (for overviews, see Nannestad 2008; Uslaner 2018b). Our findings suggest that these effects extend to the legitimacy of international institutions. We thereby join others who have identified consequences of social trust for international cooperation (Rathbun 2011). This is an important finding, since popular legitimacy often is seen to have intrinsic value, as a precious component of democratic governance, and to facilitate effective problem-solving, by paving the way for more ambitious policies and better compliance (Buchanan and Keohane 2006; Tallberg et al. 2018).

Second, the results imply that the legitimacy of international institutions partly is explained by factors beyond the control of these institutions and their member governments. The past two decades have witnessed growing public contestation of international institutions, met by intensified efforts of these institutions to legitimize themselves (O'Brien et al. 2000; Symons 2011; Zaum 2013; Gronau and Schmidtke 2015). By showing how legitimacy beliefs partly are anchored in relatively stable trust predispositions, our findings suggest that such efforts to actively shape citizens' attitudes toward international institutions are up against constraints that are relatively deeply rooted and slow to change.

Third, this article underscores the importance of studying the patterns and sources of legitimacy comparatively across international institutions. Yet, so far, this is a rare occurrence, as a consequence of the fragmented nature of existing large-scale survey data. Previous research has focused predominantly on the EU, raising questions about scope conditions and broader applicability. The comparative scope of our analysis suggests that social trust matters for attitudes toward institutions that vary significantly in issue orientation and membership scope. At the same time, the analysis points to interesting variation across countries in attitudes toward multilateral cooperation. As better comparative data on public opinion toward international institutions become available, more comprehensive tests of the arguments evaluated in this article and in other work on international legitimacy should be a priority.

Publisher's Note Springer Nature remains neutral with regard to jurisdictional claims in published maps and institutional affiliations.

Open Access This article is distributed under the terms of the Creative Commons Attribution 4.0 International License (http://creativecommons.org/licenses/by/4.0/), which permits unrestricted use, distribution, and reproduction in any medium, provided you give appropriate credit to the original author(s) and the source, provide a link to the Creative Commons license, and indicate if changes were made.

\section{References}

Ansolabehere, S., \& Schaffner, B. F. (2014). Does survey mode still matter? Findings from a 2010 multi-mode comparison. Political Analysis, 22(3), 285-303.

Ares, M., Ceka, B., \& Kriesi, H. (2017). Diffuse support for the European Union: Spillover effects of the politicization of the European integration process at the domestic level. Journal of European Public Policy, 24(8), 1091-1115.

Armingeon, K., \& Ceka, B. (2014). The loss of trust in the European Union during the great recession since 2007: The role of heuristics from the national political system. European Union Politics, 15(1), 82-107.

Beetham, D. (1991). The legitimation of power. London: Palgrave Macmillan. 
Berinsky, A. J., Huber, G. A., \& Lenz, G. S. (2012). Evaluating online labor markets for experimental research: Amazon.com's mechanical Turk. Political Analysis, 20(3), 351-68.

Bodansky, D. (1999). The legitimacy of international governance: A coming challenge for international environmental law? American Journal of International Law, 93(3), 596-624.

Bollen, K. A. (1989). Structural equations with latent variables. New York: Wiley.

Bollen, K. A., \& Pearl, J. (2013). Eight myths about causality and structural equation models. In S. L. Morgan (Ed.), Handbook of causal analysis for social research (pp. 201-328). Dordrecht: Springer.

Brehm, J., \& Rahn, W. (1997). Individual-level evidence for the causes and consequences of social capital. American Journal of Political Science, 41(9), 999-1023.

Buchanan, A., \& Keohane, R. O. (2006). The legitimacy of global governance institutions. Ethics \& International Affairs, 20(4), 405-437.

Bühlmann, M., \& Kunz, R. (2011). Confidence in the judiciary: Comparing the independence and legitimacy of judicial systems. West European Politics, 34(2), 317-345.

Bullock, J. G. (2011). Elite influence on public opinion in an informed electorate. American Political Science Review, 105(3), 496-515.

Caldeira, G. A., \& Gibson, J. L. (1995). The legitimacy of the court of justice in the European Union: Models of institutional support. American Political Science Review, 89(2), 356-376.

Chalmers, A. W., \& Dellmuth, L. M. (2015). Fiscal redistribution and public support for European integration. European Union Politics, 16(3), 386-407.

Chong, D., \& Druckman, J. N. (2007). Framing theory. Annual Review of Political Science, 10(1), $103-126$.

Converse, P. E. (1964). The nature of belief systems in mass publics. In D. E. Apter (Ed.), Ideology and discontent (pp. 206-261). New York: Free Press.

Dai, X. (2005). Why comply? The domestic constituency mechanism. International Organization, 59(2), 363-398.

Delli Carpini, M. X., \& Keeter, S. (1996). What Americans know about politics and why it matters. New Haven: Yale University Press.

Dellmuth, L. M. (2018). Individual sources of legitimacy beliefs: Theory and data. In J. Tallberg, K. Bäckstrand, \& J. A. Scholte (Eds.), Legitimacy in global governance: Sources, processes, and consequences. Oxford: Oxford University Press.

Dellmuth, L. M., \& Chalmers, A. W. (2017). All spending is not equal: European Union public spending, policy feedback and citizens' support for the EU. European Journal of Political Research, 57(1), 3-23.

Dellmuth, L. M., \& Tallberg, J. (2015). The social legitimacy of international organisations: Interest representation, institutional performance, and confidence extrapolation in the United Nations. Review of International Studies, 41(3), 451-475.

Easton, D. (1965). A systems analysis of political life. Chicago, IL: University of Chicago Press.

Easton, D. (1975). A re-assessment of the concept of political support. British Journal of Political Science, $5(4), 435-457$.

Ecker-Ehrhardt, M. (2016). Why do citizens want the UN to decide? Cosmopolitan ideas, particularism and global authority. International Political Science Review, 37(1), 99-114.

European Social Survey. (2014). ESS round 7 source questionnaire. London: ESS ERIC Headquarters, Centre for Comparative Social Surveys, City University London.

Evans, A. M., \& Revelle, W. (2008). Survey and behavioral measurements of interpersonal trust. Journal of Research in Personality, 42(6), 1585-1593.

Fiske, S. T., \& Taylor, S. E. (1991). Social cognition (2nd ed.). New York: McGraw-Hill.

Franck, T. M. (1990). The power of legitimacy among nations. Oxford: Oxford University Press.

Freitag, M., \& Bühlmann, M. (2009). Crafting trust: The role of political institutions in a comparative perspective. Comparative Political Studies, 42, 1537-1566.

Fukuyama, F. (1995). Trust: The social virtues and the creation of prosperity. New York: The Free Press.

Gabel, M. (1998). Public support for European integration: An empirical test of five theories. Journal of Politics, 60(2), 333-354.

Gabel, M., \& Scheve, K. F. (2007). Estimating the effect of elite communication on public opinion using instrumental variables. American Journal of Political Science, 51(4), 1013-1028.

Gallup International Association. (2012). Voice of the People, 2012. ICPSR 35201. Ann Arbor, MI: Inter-university Consortium for Political and Social Research. http://www.icpsr.umich.edu/icpsrweb/ICPSR/studies/35201. Accessed 05 Dec 2019.

Gigerenzer, G., \& Gaissmaier, W. (2011). Heuristic decision making. Annual Review of Psychology, 62, 451-482.

Glanville, J. L., \& Paxton, P. (2007). How do we learn to trust? A confirmatory tetrad analysis of the sources of generalized trust. Social Psychology Quarterly, 70, 230-242.

Green, D., Palmquist, B., \& Schickler, E. (2002). Partisan hearts and minds: Political parties and the social identities of voters. New Have: Yale University Press. 
Gronau, J., \& Schmidtke, H. (2015). The quest for legitimacy in world politics - International institutions' legitimation strategies. Review of International Studies, 42(3), 535-557.

Hardin, R. (2002). Trust and trustworthiness. New York: Russel Sage.

Harteveld, E., van der Meer, T., \& de Vries, C. E. (2013). In Europe we trust? Exploring three logics of trust in the European Union. European Union Politics, 14(4), 542-565.

Held, D., \& Koenig-Archibugi, M. (Eds.). (2005). Global governance and public accountability. Oxford: Blackwell.

Hooghe, L., \& Marks, G. (2005). Calculation, community and cues: Public opinion on European integration. European Union Politics, 6(4), 419-443.

Hurd, I. (2007). After anarchy: Legitimacy and power in the United Nations Security Council. Princeton: Princeton University Press.

Imai, K., Keele, L., \& Tingley, D. (2010). A general approach to causal mediation analysis. Psychological Methods, 15(4), 309-334.

Imai, K., Keele, L., Tingley, D., \& Yamamoto, T. (2011). Unpacking the black box of causality: Learning about causal mechanisms from experimental and observational studies. American Political Science Review, 105(4), 765-789.

Inglehart, R. (1997). Modernization and postmodernalization. Princeton: Princeton University Press.

Inglehart, R., \& Rabier, J. R. (1978). Economic uncertainty and European solidarity: Public opinion trends. The Annals of the American Academy of Political and Social Science, 440(1), 66-97.

Jamal, A. (2007). When is social trust a desirable outcome? Examining levels of trust in the Arab world. Comparative Political Studies, 40(11), 1328-1349.

Jamal, A., \& Nooruddin, I. (2010). The democratic utility of trust: A cross-national analysis. Journal of Politics, 72(1), 45-59.

Johnson, T. (2011). Guilt by association: The link between states' influence and the legitimacy of intergovernmental organizations. The Review of International Organizations, 6(1), 57-84.

Kahneman, D., Tversky, A., \& Slovic, P. (1982). Judgment under uncertainty: Heuristics and biases. Cambridge: Cambridge University Press.

Karp, J. A., Banducci, S. A., \& Bowler, S. (2003). To know it is to love it? Satisfaction with democracy in the European Union. Comparative Political Studies, 36(3), 271-292.

Keohane, R. O. (2011). Global governance and legitimacy. Review of International Political Economy, 18(1), 99-109.

King, G., Tomz, M., \& Wittenberg, J. (2000). Making the most of statistical analyses: Improving interpretation and presentation. American Journal of Political Science, 44(2), 347-361.

Kritzinger, S. (2003). The influence of the nation-state on individual support for the European Union. European Union Politics, 4(2), 219-241.

Lau, R. R., \& Redlawsk, D. P. (2001). Advantages and disadvantages of cognitive heuristics in political decision making. American Journal of Political Science, 45(4), 951-971.

Letki, N. (2018). Trust in newly democratic regimes. In E. M. Uslaner (Ed.), Oxford handbook of social and political trust. Oxford: Oxford University Press.

Mattes, R., \& Moreno, A. (2018). Social and political trust in developing countries: Sub-Saharan Africa and Latin America. In E. M. Uslaner (Ed.), Oxford handbook of social and political trust. Oxford: Oxford University Press.

Mondak, J. J. (1999). Reconsidering the measurement of political knowledge. Political Analysis, 8(1), 57-82.

Mondak, J. J. (2003). Public opinion and heuristic processing of source cues. Political Behavior, 15(2), 167-192.

Muñoz, J., Torcal, M., \& Bonet, E. (2011). Institutional trust and multilevel government in the European Union: Congruence or compensation? European Union Politics, 12(4), 551-574.

Nannestad, P. (2008). What have we learned about generalized trust, if anything? Annual Review of Political Science, $11,413-436$.

Newton, K., \& Norris, P. (2000). Confidence in public institutions: Faith, culture, or performance? In S. Pharr \& R. D. Putnam (Eds.), Disaffected democracies: What's troubling the trilateral countries? (pp. 52-73). Princeton: Princeton University Press.

Newton, K., \& Zmerli, S. (2008). Social trust and attitudes toward democracy. Public Opinion Quarterly, 72(4), 706-724.

Newton, K., \& Zmerli, S. (2011). Three approaches to trust. European Political Science Review, 3(2), 169-200.

Norris, P. (2000). Global governance and cosmopolitan citizens. In J. S. Nye \& J. D. Donahue (Eds.), Governance in a globalizing world (pp. 155-177). Washington, DC: Brookings Institution Press.

Norris, P. (2009). Confidence in the United Nations: Cosmopolitan and nationalistic attitudes. In Y. Esmer \& T. Petterson (Eds.), The international system, democracy and values. Uppsala: Acta Universitatis Upsaliensis.

O’Brien, R., Goetz, A. M., Scholte, J. A., \& Williams, M. (2000). Contested global governance: Multilateral economic institutions and global social movements. Cambridge: Cambridge University Press. 
Preacher, K. J., Rucker, D. D., \& Hayes, A. F. (2007). Addressing moderated mediation hypotheses: Theory, methods, and prescriptions. Multivariate Behavioral Research, 42(1), 185-227.

Putnam, R. D. (1993). Making democracy work: Civic traditions in modern Italy. Princeton: Princeton University Press.

Putnam, R. D. (2000). Bowling alone: The collapse and revival of American community. New York: Simon \& Schuster.

Putnam, R. D., Pharr, S. J., \& Dalton, R. J. (2000). Introduction: What's troubling the trilateral democracies. In S. Pharr \& R. D. Putnam (Eds.), Disaffected democracies: What's troubling the trilateral countries? (pp. 3-30). Princeton: Princeton University Press.

Rathbun, B. C. (2011). Before hegemony: Generalized trust and the creation and design of international security organizations. International Organization, 65(2), 243-273.

Rothstein, B., \& Stolle, D. (2008). The state and social capital: An institutional theory of generalized trust. Comparative Politics, 40, 441-467.

Rothstein, B., \& Uslaner, E. M. (2005). Corruption and social trust. World Politics, 58(3), 41-72.

Rotter, J. B. (1980). Interpersonal trust, trustworthiness and gullibility. American Psychologist, 35(1), 1-7.

Rubin, D. B. (1976). Inference and missing data. Biometrika, 63(3), 581-592.

Sánchez-Cuenca, I. (2000). The political basis of support for European integration. European Union Politics, $1(2), 147-171$.

Sattler, T., \& Urpelainen, J. (2012). Explaining public support for international integration: How do national conditions and treaty characteristics interact with individual beliefs? Journal of Politics, 74(4), 11081124.

Schlipphak, B. (2015). Measuring attitudes toward regional organizations outside Europe. The Review of International Organizations, 10(3), 351-375.

Simon, H. (1957). Models of man: Social and rational. New York: Wiley.

Sniderman, P. M., Brody, R. A., \& Tetlock, P. E. (1991). Reasoning and choice: Explorations in political psychology. Cambridge: Cambridge University Press.

Sommerer, T., \& Agné, H. (2018). Consequences of legitimacy in global governance. In J. Tallberg, K. Bäckstrand, \& J. A. Scholte (Eds.), Legitimacy in global governance: Sources, processes, and consequences. Oxford: Oxford University Press.

Suchman, M. C. (1995). Managing legitimacy: Strategic and institutional approaches. Academy of Management Review, 20(3), 571-610.

Symons, J. (2011). The legitimation of international organizations: Examining the identity of the communities that grant legitimacy. Review of International Studies, 37(5), 2557-2583.

Tallberg, J., Bäckstrand, K., \& Scholte, J. A. (2018). Introduction: Legitimacy in global governance. In J. Tallberg, K. Bäckstrand, \& J. A. Scholte (Eds.), Legitimacy in global governance: Sources, processes, and consequences. Oxford: Oxford University Press.

Torgler, B. (2008). Trust in international organizations: An empirical investigation focusing on the United Nations. The Review of International Organizations, 3(1), 65-93.

Tversky, A., \& Kahneman, D. (1974). Judgement under uncertainty: Heuristics and biases. Science, 185(4157), 1124-1131.

Uslaner, E. M. (2002). The moral foundations of trust. Cambridge: Cambridge University Press.

Uslaner, E. M. (2018a). The study of trust. In E. M. Uslaner (Ed.), Oxford handbook of social and political trust. Oxford: Oxford University Press.

Uslaner, E. M. (2018b). Oxford handbook of social and political trust. Oxford: Oxford University Press.

Voeten, E. (2013). Public opinion and the legitimacy of international courts. Theoretical Inquiries in Law, 14(2), 411-436.

Weber, M. ([1922] 1978). Economy and Society. Berkeley: University of California Press.

Zak, P. J., \& Knack, S. (2001). Trust and economic growth. Economic Journal, 111, 295-321.

Zaller, J. R. (1992). Nature and origins of mass opinion. New York: Cambridge University Press.

Zaum, D. (2013). Legitimating international organizations. Oxford: Oxford University Press.

Zmerli, S. (2010). EU legitimacy and social capital: Empirical insights into a complex relationship. In W. A. Maloney \& J. W. Van Deth (Eds.), Civil society and activism in Europe: Contextualizing engagement and political orientations (pp. 156-179). London: Routledge.

Zürn, M. (2018). A theory of global governance: Authority, legitimacy, and contestation. Oxford: Oxford University Press. 